\title{
The impact of regulatory reforms on cost structure, ownership and competition in Indian banking
}

Article

Accepted Version

Zhao, T., Casu, B. and Ferrari, A. (2010) The impact of regulatory reforms on cost structure, ownership and competition in Indian banking. Journal of Banking \& Finance, 34 (1). pp. 246-254. ISSN 0378-4266 doi:

https://doi.org/10.1016/j.jbankfin.2009.07.022 Available at https://centaur.reading.ac.uk/17632/

It is advisable to refer to the publisher's version if you intend to cite from the work. See Guidance on citing.

To link to this article DOI: http://dx.doi.org/10.1016/j.jbankfin.2009.07.022

Publisher: Elsevier

All outputs in CentAUR are protected by Intellectual Property Rights law, including copyright law. Copyright and IPR is retained by the creators or other copyright holders. Terms and conditions for use of this material are defined in the End User Agreement.

www.reading.ac.uk/centaur 
Central Archive at the University of Reading

Reading's research outputs online 


\title{
The impact of regulatory reforms on cost structure, ownership and competition in Indian banking
}

\author{
Tianshu Zhao \\ University of Stirling \\ Barbara Casu \\ CASS Business School \\ Alessandra Ferrari \\ University of Reading
}

\begin{abstract}
This paper aims to evaluate the impact of financial sector reforms on the cost structure characteristics and on the ownership-cost efficiency relationship in Indian banking. It also examines the impact of reforms on the dynamics of competition in the lending market. We find evidence that deregulation starts a process of improvement in banks performance and fosters competition in the lending market. Results suggest technological progress, once Indian commercial banks have adjusted to the new regulatory environment by changing both the input mix and the output composition. This, however, does not translate in efficiency gains. There is also evidence of an ownership effect on the level and pattern of efficiency change. Finally, competition keeps building pace even in the re-regulation period and technological improvements are not hampered by the tightening of prudential norms.
\end{abstract}

Key words: Deregulation; Re-regulation; Competition; Ownership; Stochastic Frontier Analysis

JEL Classification: G21; G28; G32; D24; C13 


\section{Introduction}

Financial deregulation and concomitant prudential re-regulation have recently been a dominant feature in financial markets of both developed and developing countries. On the one hand, deregulation aims to lower firms' regulatory costs and foster competition in the banking and financial sectors. The standard economic argument for the positive influence of competition on firms' performance is that the existence of monopoly rents gives managers the potential of capturing some of them in the form of slack or inefficiency (see Nickell et al., 1997). Therefore, deregulation-induced competition should in turn translate into incentives for managers to improve efficiency and performance. On the other hand, the aim of prudential re-regulation is to foster stability and minimise excessive risk taking. As a consequence, it imposes higher costs and could hamper competition, therefore resulting in a decrease in firms' efficiency and performance. Despite the fact that a deregulation-prudential re-regulation framework has widely been adopted by policy makers, relatively little empirical work has been done to evaluate the overall impact of such processes on banks' competition and efficiency. In addition, the relevance of corporate governance also remains controversial and different ownerships are found to react with different speeds to the change of regulatory environment (Isik and Hassan, 2003). This paper aims to fill these gaps in the literature, with particular reference to the reform of the Indian commercial banking sector during the period 1992-2004. The Indian reform process can be divided into two stages: a first stage of deregulation aimed at promoting competition (1992-1997) and a second stage (post 1998) aimed at strengthening financial stability (see Narasimham, 1998). In detail, this study examines the effect of the concomitant deregulation and prudential re-regulation 
framework adopted by the Indian authorities on the competitive behaviour, cost structure characteristics and efficiency of Indian commercial banks. As the overall impact of financial reforms on bank efficiency may be determined by the structure of the financial system prior to deregulation, we also specifically investigate the ownership-cost efficiency relationship. Following Battese and Coelli (1995), we employ a stochastic cost frontier approach to estimate the efficient cost structure and the determinants of cost inefficiency on a balanced panel dataset that includes public sector, domestic private and foreign banks continuously operating in India throughout the sample period. In a second step, we examine the overall impact of regulatory reform on the dynamics of competition in the lending market. Using the marginal cost of loans derived from the stochastic cost frontier, we calculate the overcharge on loans (defined as the price-marginal cost ratio). We then estimate the persistence of the overcharge through a partial adjustment model. An increased persistence of the overcharge would indicate that competitive conditions have not improved over the period of analysis and vice versa.

Our results indicate technological regress until 1996 and progress thereafter. This suggests that it takes time for banks to adjust to the newly deregulated operating environment but it also evidences a general improvement of the production technology adopted by Indian banks following the reforms. Efficiency gains seem to take place in the deregulation period, until 1997. However, the overall trend in efficiency is negative during the sample period. This could be explained by re-regulation imposing higher costs, but also by the fact that, because of the technological improvements, the average bank may find it more difficult to operate efficiently. Our results also indicate the existence of an ownership effect on the level and 
pattern of efficiency, with foreign banks losing their initial efficiency advantage in a more deregulated environment. Further, foreign banks seem initially better equipped to cope with re-regulation, but again their efficiency advantage is short lived. Finally, we find evidence that deregulation starts a process of improvement in banks performance and fosters competition on the market. Competition keeps building pace even in the re-regulation period and technological improvements are not hampered by the tightening of prudential norms.

The rest of the paper is organised as follows. Section 2 reviews the general background of the Indian banking system. Section 3 discusses the existing literature on the effects of financial reforms on banks performance and competition. Section 4 describes the methodology, the data and the variables used. The empirical results are illustrated in Section 5 and Section 6 concludes.

\section{The Indian banking sector and regulatory environment}

The Indian government started its banking sector reform in 1992. The whole reform programme was led by two Narasimham Committee reports, in 1991 and 1998 respectively. As a consequence, the reform process can be divided into two stages. The first stage relates to regulatory changes aimed at promoting competition (1992-1997). The second stage, started in 1998, aimed at strengthening financial stability.

Structural deregulation was characterised by the liberalisation of interest rates on deposits and lending; the removal of restrictions on entry and on private ownership; and the increase of the range of permissible activities. From 1998 onwards, the emphasis of the reform process focussed on the stability of the banking system. For example, prudential norms on 
assets classification, income recognition, provisioning on non-performing loans and riskbased capital requirements became progressively more important, particularly against the backdrop of the Asian crisis ${ }^{1}$. The whole reform process aimed to create a level playing field among different ownership; regulatory policies relating to interest rates, prudential norms and reserve requirements were applied uniformly across banking groups. However, priority sector credit requirements are still in place, with different targets for domestic and foreign banks $^{2}$. Table 1 illustrates the changing structure of the Indian banking sector over the reform period, with reference to scheduled commercial banks ${ }^{3}$ (excluding regional rural banks). At the end of 2004, the 27 public sector (state-owned) banks accounted for $74.5 \%$ of the market share in terms of total assets, a decrease of $16 \%$ compared to 1992 . Due to the reforms opening up the sector to private ownership, both domestic private and foreign banks increased in number and their relative market share also increased, although foreign banks still remain rather marginal, covering only $6.9 \%$ of the market in 2004 . In terms of concentration ratios, both the five firms concentration ratio (CR5) and the HerfindahlHirschman Index (HHI) show a decreasing trend over the sample period. The high CR5 but rather low HHI indicate the inequality of market shares across scheduled commercial banks.

\section{<Insert Table 1>}

Table 2 provides some descriptive statistics of selected banking indicators. The spread,

\footnotetext{
${ }^{1}$ Among the major prudential policy initiatives post-1997 were the introduction of the CAMELS (Capital adequacy, Asset quality, Management quality, Earnings, Liquidity and System evaluation) annual supervision system in 1997, the increase of the risk-based capital adequacy requirement to $9 \%$ (effective from March 2000), and the introduction of a 90-day delinquency norm for the classification of non-performing loans.

${ }^{2}$ The Indian government requires banks to allocate a specified portion of their lending (40\% for domestic banks and $32 \%$ for foreign banks) to priority sectors. Priority sectors are defined by the Reserve Bank of India and include, among others, agriculture, small scale industries, education and housing.

${ }^{3}$ Scheduled commercial banks refer to those banks that have paid up capital and reserve of no less than Rs 500,000 and other conditions specified by the Banking Regulation Act of 1965. Scheduled commercial banks consist of public, private, foreign and regional rural banks.
} 
measured both as the difference between the implicit credit rate and deposit rate, and as the gap between the implicit credit rate and the average price of loanable funds, is decreasing over time, which is consistent with increased competition fostered by the reform process. The data also reveal a growing preference for safer, more liquid other earning assets, especially government securities. Lending, as a ratio of total earning assets, decreases whilst investment increases. Moreover, the ratio of government and other approved securities to deposits (the statutory liquidity ratio, or SRL) remains higher than the prescribed minimum level over the whole sample period ${ }^{4}$. Finally, the data show that the ratio of fee-based income to total income increased from $13.4 \%$ in 1992 to $23.7 \%$ in 2004 . This may suggest an attempt of banks to reduce the impact of the decreasing spread on profits by shifting the business focus from traditional on balance sheet business towards fee-based, non-traditional off-balance sheet business, which has become available owing to the removal of the restriction on activities in the deregulated operational environment.

\section{<Insert Table 2>}

\section{Literature review}

According to microeconomic theory, deregulation should positively affect the efficiency and productivity of the banking industry as it reduces the regulatory cost imposed on market participants. In addition, increased competition fostered by deregulation should induce banks to minimise costs to maintain market shares and profitability. However, the empirical evidence is mixed: deregulation seems to have had a positive effect on the banking sectors in some countries but not in others (Berger et al., 2000a). Controversy is not only related to the

\footnotetext{
${ }^{4}$ The prescribed SRL was 38.5\% in 1991-1992 and was progressively reduced to $25 \%$ from 1997 onwards.
} 
overall efficiency and productivity improvements, but also to the manner in which these improvements take place: in some countries deregulation mainly promotes efficiency, whilst in others it appears to stimulate technological progress (Zhao et al., 2008). Indeed, the outcome of deregulation policies may reflect several country-specific demand and supply conditions of the banking industry prior to deregulation.

Whilst several studies investigate the link between market structure indicators (such as concentration ratios) and performance in the traditional Structure-Conduct-Performance (SCP) context, such studies typically do not explicitly incorporate the effect of regulation, nor do they analyse whether regulatory changes strengthen or weaken this link (Gilbert, 1984). There is no conclusive evidence on how regulatory changes in the late 1990s have affected the structure, conduct and performance relationship in the financial sector. The New Empirical Industrial Organization (NEIO) literature, on the other hand, departs from the SCP paradigm and attempts to infer the degree of competition in the market by analysing firms' conduct. The empirical evidence provided by NEIO studies, however, fails to identify increased competition following the rapid deregulation and liberalisation processes in the EU area (Maudos and Fernandez De Guevara, 2004; Fernandez De Guevara et al., 2005), or in the UK banking system (Matthews et al., 2007). The fact that competition does not always increase following a period of deregulation may be explained by the fact that in most countries a parallel process of prudential re-regulation has taken place. Regulatory reform is often a mixed process of deregulation and prudential re-regulation and therefore the net effect on competition is not clearly identifiable.

Both the SCP and the NEIO approaches, though, are based on static models of competitive 
equilibrium. On the other hand, the persistence of profit (POP) hypothesis (Mueller, 1977, 1986) posits that if entry and exit are sufficiently free, this would quickly eliminate any abnormal profit and all firms' profits would tend to converge toward the same long run average. However, if abnormal profits tend to persist from year to year, then there might be barriers to entry or banks might be exploiting monopoly power. Empirical tests of the POP hypothesis in banking include Berger et al. (2000b), who use a non-parametric measurement of persistence in the US, and Goddard et al. (2004a, 2004b) who estimate a parametric model for the EU. Both studies presented some evidence of persistence of profit.

Another issue of relevance relates to the impact of regulatory reform and increased competition on the ownership structure of banks. In theory, increased competition should provide incentives to managers to improve efficiency regardless of the type of ownership. In other words, the stronger the competitive pressure, the less relevant the ownership structure should become for productive efficiency (Vickers, 1995; Allen and Gale, 2000). In empirical studies, however, ownership structure does not appear to be neutral in terms of changes in efficiency and productivity following financial reforms. While deregulation seems to increase efficiency for all banks, it does not result in inter-ownership convergence (Bonaccorsi di Patti and Hardy, 2005). Different ownerships are found to react with different speeds to the change of regulatory environment (Isik and Hasan, 2003; Leightner and Lovell, 1998). Domestic private banks are often found to perform better than government-owned banks, although some disagreement remains in the literature (Megginson, 2005). Foreign banks are found to perform better than domestic banks in developing countries, while in developed countries the opposite is true (Berger et al., 2000a; Berger et al., 2004). 
The empirical literature analysing the impact of the substantial transformation of the Indian banking system on bank efficiency and competition suggests a decrease in cost efficiency post-1992 (Kumbhakar and Sarkar, 2005; Sensarma, 2005). Das and Ghosh (2006) attribute the high cost inefficiency both to the under-utilisation of resources and to the scale of operations. Kumbhakar and Sarkar (2003) fail to identify a significant impact of regulatory reform on total factor productivity growth. Zhao et al. (2008) identify sustained productivity growth in the post-reform period, driven mainly by technological progress. Empirical results also provide little evidence to suggest that public sector banks are less cost efficient than their domestic private and foreign counterparts (Sensarma, 2005; Zhao et al, 2008). With respect to the competitive conditions of the Indian banking market, Prasad and Ghosh (2005) estimate the H-statistic and conclude that, while the Indian banking system is characterised by monopolistic competition, there is evidence of increased competition in the period 20002004 compared to 1996-1999.

Our study contributes in several ways to the existing literature and the paucity of systematic studies on the impact of policy changes onto banks competition and performance. Our empirical analysis covers the whole period of Indian reforms, which allows us to properly test their overall impact on banks cost performance in general and on the ownership-cost efficiency relationship in particular. Since the deregulation and re-regulation policies could have opposite, complementary effects on market competition, which is expected to be the main channel through which improvements are meant to take place, we also separately test for the dynamics of competition by estimating a partial adjustment model, in line with the POP literature approach. 


\section{Methodology}

\subsection{Variables and data}

To carry out our empirical analysis, we estimate two models: a cost frontier (which requires the identification of output and input price variables) and a partial adjustment model (which requires the estimation of the overcharge on loans, the price to marginal cost ratio). For our variables definition we broadly follow the intermediation approach (Sealey and Lindley, 1977) and use a two-input, three-output specification. The first output is the book value of performing loans, measured as the difference between total loans and non-performing loans. This is to control for loan quality, given the existence of high levels of non-performing loans in the Indian banking system and the heterogeneity in the quality of loans among individual banks. The imputed price of loans is calculated as the ratio of interest received on loans over total performing loans ${ }^{5}$. The second output is "other earning assets", increased presence on banks' balance sheet. Finally, we define fee-based income as the third output to accommodate the shift of banks' business focus from traditional on-balance-sheet activities to non-traditional off-balance-sheet activities.

Two inputs are selected to match the characteristics of the three specified outputs. The first input - total loanable funds - sums deposits and money market funding, and its price is calculated as the ratio of total interest expenditure to total loanable funds. The second input non-interest operating costs - aggregates the expenditure associated with labour and physical capital; its price is given by the ratio between non-interest operating cost and total assets.

\footnotetext{
${ }^{5}$ According to the accounting practice followed by the Indian banking sector post-1992, income accrual would cease once the loan is recognized as non-performing. Therefore, the interest received on loans recorded in the loss and profit account is associated with the performing loans.

${ }^{6}$ Other earning assets aggregates government securities, other approved securities, share, debentures and bonds, subsidiaries and joint ventures and other investment outside India (i.e. total investment).
} 
The data, collected from the Reserve Bank of India, cover continuously operating Indian commercial banks (excluding regional rural banks) throughout the period 1992-2004, encompassing the whole reform experience. Given our interest in the behavioural characteristics of banks, along with the substantial changes in the operational environment during the reform, focusing on banks that were continuously operating is all the more important. If banks merged during the period of observation, we chose to aggregate their financial statements and treat them as a single composite bank for the entire period. The data set contains 13 years of accounting data for 65 banks (27 public, 20 domestic private and 18 foreign), for a total of 845 observations. All data were deflated using the GDP deflator using 1991 as the base year.

Table 3 presents some general statistics of the data set at the industry level and per ownership category.

\section{Insert Table 3 here}

As can be seen in Table 3, the mean of total cost and of all the 3 outputs is always larger than the median, indicating a distribution skewed to the right; this is due to the larger market share of public banks revealed also in Table 1. Indeed the average for public banks is always almost twice the industry average, and they always account for the maximum value at industry level, whereas the shares of domestic private and foreign banks are remarkably lower. The two inputs prices have instead a much smaller variation, and the correlations between the variables ${ }^{7}$ are all of the expected sign.

\footnotetext{
${ }^{7}$ Since they are not particularly revealing these are not reported in the paper for reasons of space.
} 


\subsection{Model specification}

To answer the first research question (the effect of regulatory reform on the cost efficiency of the Indian banking sector) we follow Battese and Coelli ${ }^{8}$ (1995) and estimate a stochastic cost frontier simultaneously with the determinants of cost inefficiency, using a one-step Maximum Likelihood estimation. There are several reasons behind the choice of this model. First of all a cost frontier, as opposed to an "average" cost function, allows one to separate and compare the behaviour of the best practices with the rest of the sample. Secondly, the choice of a frontier with inefficiency determinants not only answers one of the key questions of the paper (the relationship between ownership and efficiency) but it is also the most unrestricted model within which other frontier specifications are embedded. As will be more apparent below, if the chosen covariates for inefficiency are not significant the model falls back to a truncated-normal frontier specification, which in turn nests the half normal specification; if inefficiency is not significant at all then the model falls back to a cost function. All these hypotheses can be tested and the results are specified and discussed in

\section{Section 5.}

In general terms, the stochastic cost frontier model is specified in log-linear form as ${ }^{9}$ :

$$
\ln V C_{i t}=f\left(X_{i t} ; \beta\right)+v_{i t}+u_{i t}
$$

and

$$
u_{i t}=\delta^{\prime} Z_{i t}+\varepsilon_{i t}
$$

where $\mathrm{VC}$ is total variable cost, $\mathrm{X}$ is a set of independent variables (inputs prices, output

\footnotetext{
${ }^{8}$ Fries and Taci (2005) review the advantages of using a one-step estimation of the determinants of inefficiency over the alternative two step estimation. See also Kumbhakar and Lovell (2003) for a complete methodology review on incorporating exogenous influence on efficiency.

${ }^{9}$ For a complete summary of both the theory and techniques used in frontier production, cost and profit analysis, see Kumbhakar and Lovell (2003).
} 
levels and other exogenous factors), and $\beta$ is a vector of technological parameters to estimate. Random errors are represented by $\mathrm{v}_{\mathrm{it}} \sim \operatorname{iidN}\left(0, \sigma_{v}{ }^{2}\right)$, whereas cost inefficiency is represented by $\mathrm{u}_{\mathrm{it}}$, which is non-negative and assumed to be independently but not identically distributed, and follows a truncated-normal distribution with constant variance, that is $\mathrm{u}_{\mathrm{it}}$ $\sim \mathrm{N}^{+}\left(\delta^{\prime} \mathrm{Z}_{\mathrm{it}}, \sigma_{\mathrm{u}}^{2}\right)$. The distribution of $\mathrm{v}_{\mathrm{it}}$ is assumed to be independent of the Xs as well as of $\mathrm{u}_{\mathrm{it}}$.

Equation (2) further specifies the determinants of inefficiency, a set of bank-specific explanatory variables $Z$, with parameters $\delta$ to be estimated. The random error component $\varepsilon_{\text {it }}$ $\sim \mathrm{N}\left(0, \sigma_{\varepsilon}^{2}\right)$ is truncated at the variable point $-\delta^{\prime} \mathrm{Z}_{\mathrm{it}}$ to allow for the non-negativity constraint on $\mathrm{u}_{\mathrm{it}}$, so that $\varepsilon_{\mathrm{it}} \geq-\delta^{\prime} \mathrm{Z}_{\mathrm{it}}$. The errors are assumed to be independently but not necessarily identically distributed, nor are required to be non-negative.

The stochastic frontier briefly described in (1) is modelled using a translog functional form, (Diewert and Wales, 1987), as:

$$
\begin{aligned}
& \ln V C_{i t}=\beta_{0}+\sum_{m=1}^{3} \alpha_{m} \ln y_{m i t}+\sum_{n=1}^{2} \beta_{n} \ln w_{n i t}+\sum_{m=1}^{3} \sum_{j=1}^{3} \alpha_{m j} \ln y_{m i t} \ln y_{j i t}+\sum_{n=1}^{2} \sum_{k=1}^{2} \beta_{n k} \ln w_{n i t} \ln w_{k i t} \\
& +\sum_{n=1}^{2} \sum_{m=1}^{3} \gamma_{n m} \ln w_{n i t} \ln y_{m i t}+\theta T+\lambda T^{2}+\sum_{m=1}^{3} \theta_{m} T \ln y_{m i t}+\sum_{n=1}^{2} \zeta_{n} T \ln w_{n i t} \\
& +a_{r} R+\sum_{m=1}^{3} \ell_{m} R \ln y_{m i t}+\sum_{n=1}^{2} \rho_{n} R \ln w_{n i t}+\alpha_{T} R T+v_{i t}+u_{i t}
\end{aligned}
$$

In (3), $\mathrm{VC}$ is total variable cost, $\mathrm{y}_{\mathrm{m}}$ are the three outputs and $\mathrm{w}_{\mathrm{n}}$ are the two inputs prices discussed in Section 4.1. Linear homogeneity in input prices is imposed prior to estimation; following standard practice, we normalise each input and output variable by its geometric mean, so that the estimated first-order coefficients measure directly the cost elasticity at the sample mean. $\mathrm{T}$ is a time trend variable, introduced quadratically as a proxy for a non- 
monotonic pattern of the changes in cost technology.

The interaction between $\mathrm{T}$ and the price and outputs variables models non-neutral and scale augmenting technology change respectively. Technological biases are more likely to occur in the case of multiple inputs - multiple outputs production ${ }^{10}$ (Balk, 2001) and their presence is well documented in the literature on the banking industry (see Altunbas et al., 1999 among others). This can have significant consequences in the context of a changing regulatory environment (Stevenson, 1980; Paul, 1999).

To isolate and investigate the impact of the shift of policy focus (from 1998 onwards) on the efficient cost structure, we specify a bilateral policy-shift dummy $\mathrm{R}$, which takes value 0 for 1992-1997 and value 1 for 1998-2004. Moreover, following Gollop and Roberts (1983) we allow the policy shift dummy to interact with time, input prices and output quantities to evaluate the response of the "best practices" in terms of output composition and input mix specifically associated with the shift of policy focus rather than with the simple passing of time ${ }^{11} \cdot v_{\text {it }}$ and $u_{\text {it }}$ are defined as before.

Coming to the cost inefficiency model of equation (2) this is fully specified as:

$$
\begin{aligned}
& u_{i t}=\delta_{0}+\delta_{1} D_{F}+\delta_{2} D_{P}+\delta_{3} D_{F} T+\delta_{4} D_{P} T+\delta_{5} T+\delta_{6} R+\delta_{7} R T+\delta_{8} R D_{F} \\
& +\delta_{9} R D_{P}+\delta_{10} R D_{F} T+\delta_{11} R D_{P} T+\delta_{12} T^{2}+\varepsilon_{i t}
\end{aligned}
$$

Equation (4) includes 12 explanatory variables to reflect the effect of time, of the change of policy focus, of ownership as well as their interactive terms. The introduction of the

\footnotetext{
${ }^{10}$ Fare et al., (1997) state the stringent conditions under which those biases would not exist.

${ }^{11}$ Although the dummy $\mathrm{R}$ is related to time, it is possible to identify its effects on cost since it is not a linear function of the time trend variable (T) (Kumbhakar and Lozano-Vivas, 2005)
} 
interactive terms facilitates the examination of the inter-ownership cost efficiency differences and their change over time. $D_{F}$ and $D_{P}$ are dummy variables set equal to 1 for foreign and domestic private banks respectively, and 0 otherwise; public sector banks are therefore the reference ownership category. $\mathrm{R}, \mathrm{T}$ and $\varepsilon_{\mathrm{it}}$ are defined as before.

To answer the second research question, i.e. the impact of regulatory reform on the dynamics of competition, we use a partial adjustment $\mathrm{AR}(1)$ model $^{12}$ in line with the POP literature's idea that persistence of profitability (measured as the gap between price and marginal cost) becomes less likely with increased competition, whilst controlling for macro and industry level external shocks. While the estimated persistence parameter of the widely used AR(1) process is explained as a signal of the strength of competition (Geroski, 1990; Glen et al., 2003), our analysis directs the unspecified structural model of the POP literature to the profit maximizing behaviour of banks and thus provides us with a stronger theoretical basis for the empirical representation of competitive dynamics.

We concentrate the analysis on the lending market, implicitly assuming that credit intermediation still represents the predominant activity of banks, and assume that banks are price-setting profit maximizers. Changes in price reflect banks' perception of changes in competitive conditions in the lending market: an increase in the perceived intensity of competition forces banks to adjust the overcharge. Ultimately, if competition were perfect price would equal marginal cost, so the ratio would be equal to one. Taking the marginal cost as the benchmark price under perfect competition, the adjustment of the overcharge towards unity indicates the dynamic evolution from imperfect toward perfect competition. Our partial

\footnotetext{
${ }^{12}$ For a review of the application of the persistence of profitability in banking see Goddard et al. (2004b).
} 
adjustment model is given by:

$$
\left(\ln m k_{i t}-\ln m k_{i(t-1)}\right)=\beta\left(\ln m k_{i t}{ }^{*}-\ln m k_{i(t-1)}\right)+\delta R\left(\ln m k_{i t} *-\ln m k_{i(t-1)}\right)+\lambda_{T} T D+\varepsilon_{i t}
$$

In (5), $m k_{i t}$ is the overcharge on performing loans at time $t$, defined as the ratio of their imputed price over their marginal cost (as estimated from (3) which therefore logically precedes $\mathrm{it})^{13}, \mathrm{mk}_{\mathrm{i}(\mathrm{t}-1)}$ is the overcharge at time $t-1 . m k_{i t} *$ is the overcharge under perfect competition, i.e. unity (and therefore zero when taking logs). TDs are time dummies used to capture exogenous external industry and macro level variables such as the growth of demand for bank loans, competitive pressure on the banking industry as a whole imposed by other segments of the financial market, monetary policy and macroeconomic shocks, the opacity of the informational environment in the credit market, etc. These variables might cause asymmetric changes in costs and in the profit maximizing price and thus need to be controlled for. $\varepsilon_{\mathrm{it}}$ is the disturbance term, and $\varepsilon_{\mathrm{it}} \sim \mathrm{iid}\left(0, \sigma^{2}\right)$. R is the bilateral policy-shift dummy, defined as before. $\beta$ is the adjustment parameter, measuring the speed of adjustment towards a value of unity of the overcharge, with $0<\beta<1$. The interaction term between $R$ and $\left(\operatorname{lnmk}_{\mathrm{it}}{ }^{*}-\ln \mathrm{mk}_{\mathrm{it}}\right)$ allows for a change in the speed of adjustment between 1992-1997 and 1998-2004; again $0<(\beta+\delta)<1$. A significant positive $\delta$ would imply a faster adjustment speed towards perfectly competitive prices (and vice versa) in 1998-2004, when the policy focus was changed, therefore indicating stronger competition. Finally, the vector $\lambda_{\mathrm{T}}$ measures the impact of the external macro-level variables on the change of overcharge.

\footnotetext{
${ }^{13}$ In our estimation, the overcharge is estimated on performing loans, thereby controlling for the riskiness of banks loan portfolios. Since we use the imputed price of performing loans, we are considering the aggregate average interest rate and do not consider the impact of non-price loan characteristics, such as different maturity structures, different amounts, etc., on the interest rate charged on loans. However, as we are interested in the evolution of the ratio of price over marginal cost, rather than in the absolute level of price, this omission should not have a significant impact on our findings. A similar approach was followed by Pinho (2000).
} 
Rearranging equation (5), we get:

$\ln m k_{i t}=\alpha \ln m k_{i(t-1)}+\gamma_{p} R \ln m k_{i(t-1)}+\lambda_{T} T D+\varepsilon_{i t}$

where $\alpha=1-\beta$ and $\gamma_{\mathrm{p}}=-\delta$. In (6) the value of $\alpha$ measures the persistence of $m k_{i t-1}$ into $m k_{i t}$.

A significantly negative value for $\gamma_{\mathrm{p}}$, corresponding to a significantly positive $\delta$, would suggest a reduction in the persistence of the overcharge in the period 1998-2004 compared to 1992-1997 (and viceversa), which in turn could indicate an increase in the intensity of competition.

\section{Empirical results}

\subsection{The Stochastic frontier model}

The simultaneous ML estimation of equations (3) and (4) was performed using the programme FRONTIER 4.1 (Coelli, 1996). To check the model robustness, a series of hypotheses related to the nature of the frontier model ${ }^{14}$ and to the consistency of the cost function with its theoretical properties ${ }^{15}$ was tested on the first set of results by means of Likelihood-ratio (LR) tests. The null hypothesis was rejected at a $1 \%$ level of significance in all cases except for the joint significance of the interaction between the policy-shift dummy and the other variables. Moreover, the presence of these interactive terms appeared to be inconsistent with the regularity conditions of the function with respect to the input prices at the sample mean. We therefore decided to withdraw these variables and re-estimate

\footnotetext{
${ }^{14}$ The following hypotheses were tested: the adequacy of a more restrictive Cobb-Douglas functional form; the existence of technological change; the existence of non-neutral technological change; whether technology is homothetic; the significance of a policy-shift effect; the significance of a policy-shift bias towards one particular input or output; the significance of inefficiency; the stochastic nature of inefficiency; the overall significance of the inefficiency model.

${ }^{15}$ Lack of consistency would lead to draw biased policy implications, as suggested by Salvanes and Tjotta (1998). The hypotheses tested include a non-negative marginal cost and the monotonicity and concavity in input prices. Homogeneity with respect to input prices is imposed prior to estimation.
} 
equations (3) and (4). The new estimations passed all the tests and the results are reported in Table 4, which shows that 19 out of the 22 parameters of the cost frontier and 11 out of the 13 parameters of the cost inefficiency model are significant at the $10 \%$ level $^{16}$.

\section{<Insert Table 4>}

Looking at Table 4, the results on the quadratic time trend indicate technological regress until 1996, with costs increasing until then and decreasing thereafter. This non-monotonic pattern could reflect the initial difficulties faced by banks to adjust the high and rigid cost structure inherited from the pre-reform period to the new operating environment. This improvement is temporarily interrupted in 1998 by the change in policy focus from fostering competition to emphasising supervision, as the significantly positive coefficient of the dummy variable $\mathrm{R}$ indicates an upward shift of the cost frontier. However this comes as a one-off additional regulatory cost and does not further affect the change in banks output composition or their input mix, since the policy-shift bias indicators were found jointly insignificant. Recalling the consultative and gradual approach of the Indian reforms, this may reflect the groundwork that banks made for the forthcoming policy change, with especially the best practices (whose behaviour is captured by the efficient frontier) being forward-looking and thus preparing well in advance for regulatory changes. Looking more closely at the technological changes, total cost elasticity increases from a value of 0.984 in 1992 to one of 0.996 in 2004, indicating that overall banks are enjoying very mild, though statistically non significant, economies of scale that get exhausted with the passing of time. The overall minimum efficient production scale decreases over time (i.e. $\theta_{1}+\theta_{2}+\theta_{3}>0$ ) but

\footnotetext{
${ }^{16}$ Lower levels of significance on the translog are not uncommon due to the presence of the quadratic and interactive terms.
} 
this is attributable only to the production of other earning assets, as their coefficient of time variation, $\theta_{2}$, is the only positive one. This could seem to contradict the increase in their holdings on banks balance sheets, although the effect is quantitatively very small $(0.016 \%)$. It is therefore possible that banks incentives to increase the proportion of other earning assets may be attributable to a wider cost-benefit analysis of their portfolio composition in the changing regulatory environment, in particular with the implementation of prudential norms. With regards to the possible non-neutral technology change, the negative and significant $\zeta$ parameter suggests that the estimated efficient cost share of loanable funds relative to other non-interest operating cost decreases over time, possibly as a consequence of banks' expectations of an increase in their price induced by increased competition. The complementary increase in the share of non-interest operating costs may also reflect the increasing effort of banks to clean up their balance sheet, in line with the implementation of prudential norms.

Turning to the characteristics of inefficiency, this is overall significant and shows a general non-monotonic pattern over time. Overall the main efficiency gains take place in the period 1992-1997: this goes hand-in-hand with deregulation as well as with the initial worsening of the frontier explained before. In 1998-2004 the general trend in efficiency is instead negative, so that overall the industry average decreases from $95.2 \%$ in $1992-1997$ to $83.4 \%$ in 1998-2004. This could be explained both by the change in policy focus per se as well as by the fact that this comes as a one-off cost to the industry and does not hinder the technological improvements initiated under deregulation. This may therefore explain why, on average, banks find it more difficult to perform efficiently. Finally this negative trend is part 
of a more general concave pattern, indicating that the worsening in performance slows down over time. What is interesting is that the speed and direction of these adjustments vary across ownership types, as shown in Figure 1. At the beginning of the sample period foreign banks have a significantly higher cost efficiency than public banks $\left(\delta_{1}<0\right)$, presumably due to their relatively stronger operating background. This advantage however decreases over time $\left(\delta_{3}>0\right)$ : by the time the policy focus changes, public banks have increased their efficiency $\left(\delta_{6}<0\right)$, whereas foreign banks have worsened their position $\left(\delta_{8}>0\right)$. The implementation of tighter prudential norms sees foreign banks initially better equipped to adapt than public banks $\left(\delta_{10}<0\right.$ and $\left.\delta_{7}>0\right)$, with the latter worsening their position at a slightly faster rate. The general efficiency trend during this time is however overall negative for both ownerships: by 2004 public banks average efficiency has decreased from $96.8 \%$ to $75.8 \%$, and foreign banks' from $90.9 \%$ to $66.7 \%$. Domestic private banks have a much lower cost efficiency than public banks for most of the period 1992-1997 $\left(\delta_{2}>0\right)$. This may be due to their particular operational situation, since they are the smaller domestic banks that remained privately owned following two rounds of nationalisation ${ }^{17}$. Their operating conditions were initially relatively weak and they presumably feared of being nationalised if they became wellestablished (Bhattacharya et al., 1997). They do display an improvement in efficiency during the period 1992-1997 $\left(\delta_{4}<0\right)$, but they do not seem to achieve significant progress (as indicated by the negative but not significant value of $\delta_{9}$ ) and they also adapt worse than public banks to the new policy measures $\left(\delta_{11}>0\right)$ so that in 2004 they are the least efficient group, with an average of $65.5 \%$.

${ }^{17}$ The Indian government nationalised 14 large domestic private banks in 1969 and another 6 banks in 1980. In 1980, banks nationalisation was carried out according to a strict cut-off rule, whereby the government took control of those banks whose aggregate (all-India) deposits were greater than Rs. 2 billion. 
This uneven impact of the shift of policy focus on the time pattern of efficiency among different ownerships probably stems from their different customer base. As pointed out by Berger et al. (2006), the customer base of foreign banks is characterised by large, well established and credit-worthy firms; the main customers of domestic private banks are informationally opaque small firms (SMEs) whilst the majority of customers of public banks are state-owned firms. The finding that foreign banks adapt better to the post-1997 policy measures may be attributed to the higher quality of their customer base, as well as to their operational structure and international standards. Similarly, the finding that domestic private banks suffered the most post-1997 could be related to their customer base, since tighter prudential norms presumably have a negative impact on the provision of financial services to SMEs. This is consistent with the empirical evidence on the association between the reduction in supervisory toughness and the increase in SMEs lending during the period 199398 in the U.S (Berger et al., 2001). To summarise, our results indicate the existence of an ownership effect on the level and the pattern of cost efficiency, and also that the external regulatory environment impacts on it. Particularly, our model identifies two rounds of interownership reshuffle in terms of cost inefficiency. The first round (during the period 19921997) shows the progressive adjustment and the opportunity seeking behaviour of banks in response to the increasing functional autonomy and operational freedom. The second round (1998-2004) emphasises the different degrees of pressure perceived by different ownerships under tighter prudential norms.

\subsection{The dynamics of competition in the lending market}

As explained in Section 4.1, the impact of regulatory changes on the dynamics of 
competition in the lending market is analysed via the examination of the persistence of the overcharge, as modelled by equation (6). The assumption behind our partial adjustment model is that the pricing behaviour of banks mirrors their perception of the intensity of competition in the market place, so that an increase in the perceived intensity of competition will compel them to set the price closer to their marginal cost at a faster speed, therefore reducing the persistence of the overcharge. Equation (6) is estimated by pooled OLS, and the results are showed in Table 5.

\section{$<$ Insert Table 5 here $>$}

The estimated coefficient on the one-period lag of the overcharge is $\alpha$ for 1992-1997 and $\alpha+\gamma_{\mathrm{p}}$ for $1998-2004$. Both $\alpha$ and $\gamma_{\mathrm{p}}$ are statistically significant, at the $1 \%$ and $7 \%$ levels respectively. The significantly negative $\gamma_{p}$, the coefficient of the interaction between $R$ and the lag of the overcharge on loans, indicates faster adjustment speed after 1997 and therefore suggests that competitive market forces become stronger in the latter stages of the reform. Our estimated persistence parameters are quite high (0.87 for 1992-1997, and 0.76 for the period of 1998-2004) compared with those obtained in other studies ${ }^{18}$ probably because by looking specifically at the convergence of price towards marginal cost we set a higher benchmark on the convergence process.

To summarise the evidence from both models, the picture they reveal is the following. Deregulation seems to starts a process of improvement in banks performance and increases competition on the market. This process needs time to build up, and initial adjustment costs are followed by technological progress after 1996, with banks progressively changing their

\footnotetext{
${ }^{18}$ For example Goddard et al., (2004b) estimate a persistence of profitability parameter of 0.439 in a study on banks in the six largest European countries.
} 
inputs mix and output composition. The change in policy focus in 1998 comes as a one-off cost to the sector, for competition keeps building pace even in the re-regulation period and technological improvements are not hampered by the tightening of prudential norms. Inefficiency is significant and differences in ownership show up mainly as differences in the speed of adjustment. Consistently with the changes in the frontier, efficiency improves mainly in the first period and, on average, it decreases afterwards. Public banks start off as less efficient than foreign banks but catch up fairly quickly. Even though by 1998 they have worsened their position foreign banks react more quickly to the new changes in the regulatory environment.

\section{Conclusions}

Using a balanced panel dataset covering continuously operating public sector, domestic private and foreign banks throughout the period 1992-2004, we examined the impact of a deregulation - prudential re-regulation framework on the characteristics of the competitive behaviour, cost structure and on the ownership-cost efficiency relationship of Indian commercial banks. Our results indicate that Indian commercial banks have been changing both their input mix and output composition to accommodate the changes in the regulatory environment. Pure cost technology worsens at the initial stages of the reform, possibly due to the rigid cost structure inherited from the pre-reform period, but improves after 1996 as market participants adjust and take advantage of the new opportunities. Except for the upward shift of the cost frontier after 1997, there is no significant structural break in the efficient cost function associated with the change of policy focus, a signal that the best practices among Indian commercial banks accomplished the majority of the adjustments to 
their production process before the change in policy measures. Our results also suggest that the ownership-cost efficiency relationship is affected by the reforms. The analysis of the dynamics of competition in the lending market suggests stronger competitive market forces in 1998-2004, despite tighter prudential norms. These results are consistent with the appearance of pure cost technology progress during the same period. Therefore, prudential re-regulation may not necessarily come at the cost of competition. 


\section{References}

Allen, F., Gale, D., 2000. Corporate Governance and Competition, in: Vives, X. (Eds.), Corporate Governance: Theoretical and Empirical Perspectives, Cambridge University Press, London, pp. 23-94.

Altunbas, Y., Goddard, J., Molyneux, P., 1999. Technical change in banking. Economics Letters 64, 215-221.

Balk, B., 2001. Scale efficiency and productivity change. Journal of Productivity Analysis $15,159-183$.

Battese, G. E., Coelli, T. J., 1995. A model for technical inefficiency effects in a stochastic frontier production function for panel data. Empirical Economics 20, 325-332.

Berger, A., De Young, R., Genay, H., Udell, G., 2000a. Globalisation of financial institutions: Evidence from cross-border banking performance. Brookings-Wharton Papers on Financial Service 3, 23-120.

Berger, A., Seth, D. B., Covitz, D. M., Hancock, D., 2000b. Why are bank profits so persistent? The roles of product market competition, information opacity and regional macroeconomic shocks. Journal of Banking and Finance 24, 1203-1235.

Berger, A., Kyle, M., Scalise, J., 2001. Did U.S. bank supervisors get tougher during the credit crunch? Did they get easier during the banking boom? Did it matter to bank lending? In: Mishkin, F. (Eds.), Prudential Supervision: What Works and What Doesn't. National Bureau of Economic Research, University of Chicago Press, Chicago, pp. 301-349.

Berger, A., Demirgüç-Kunt, A., Levine, R., Haubrich, J. G., 2004. Bank concentration and competition: An evolution in the making. Journal of Money, Credit \& Banking 36, 433-451. 
Berger, A., Klapper, L. F., Peria, M. S. M., Zaidi, R., 2006. The effect of bank ownership type on banking relationship and multiple banking in developing economies detailed evidence from India. World Bank Policy Research Working Paper 3862.

Bonaccorsi di Patti, E., Hardy, D., 2005. Financial sector liberalization, bank privatization, and efficiency: Evidence from Pakistan. Journal of Banking and Finance 29, 2381-2406.

Coelli, T. J., 1996. A guide to FRONTIER version 4.1: A computer program for frontier production function estimation. CEPA working paper 96/07, Department of Econometrics, University of New England.

Das A., Ghosh S., 2006. Financial deregulation and efficiency: An empirical analysis of Indian banks during the post-reform period. Review of Financial Economics 15, 193 -221.

Diewert, W. E., Wales, T. J., 1987. Flexible functional forms and global curvature conditions. Econometrica 55, 43-68.

Fare, R., Grifell-Tatje, E., Grosskopf, S., Lovell, C.A. K., 1997. Biased technical change and the Malmquist productivity index. Scandinavian Journal of Economics 99, 119-127.

Fernandez De Guevara, J., Maudos, J., Perez, F., 2005. Market power in European banking sectors. Journal of Financial Services Research 27, 109-137.

Fries, S., Taci, A., 2005. Cost efficiency of banks in transition: Evidence from 289 banks in 15 post-communist countries. Journal of Banking and Finance 29, 55-81.

Geroski, P., 1990. Modeling persistent profitability, in: Mueller, D. (Eds.), The Dynamics of Company Profits: An International Comparison, Cambridge: Cambridge University Press, pp. $147-67$.

Gilbert, A., 1984. Bank market structure and competition. Journal of Money, Credit, and 
Banking 16, 617-645.

Glen, J., Lee, K., Singh, A., 2003. Corporate profitability and the dynamics of competition in emerging markets: A time series analysis. Economic Journal 113, F465-F484.

Goddard, J., Molyneux, P., Wilson, J. O. S., 2004a. The profitability of European banks: A cross-sectional and dynamic panel analysis. The Manchester School 72, 363-381.

Goddard, J., Molyneux, P., Wilson, J. O. S., 2004b. Dynamics of growth and profitability in banking. Journal of Money, Credit and Banking 36, 1069-90.

Gollop, F. M., Roberts, M. J., 1983. Environmental regulations and productivity growth: the case of fossil-fuelled electric power generation. Journal of Political Economy 91, 654-674.

Isik, I., Hassan, M. K., 2003. Financial deregulation and total factor productivity change: An empirical study of Turkish commercial banks. Journal of Banking and Finance 27, 14551485.

Kumbhakar, S. C., Lovell, C. A. K., 2003. Stochastic Frontier Analysis. Cambridge: Cambridge University Press.

Kumbhakar, S. C., Lozano-Vivas, A., 2005. Deregulation and productivity: The case of Spanish banks. Journal of Regulatory Economics 27, 331-351.

Kumbhakar, S. C., Sarkar, S., 2003. Deregulation, ownership and productivity growth in the banking industry: Evidence from India. Journal of Money, Credit, and Banking 35, 403-414. Kumbhakar, S. C., Sarkar, S., 2005. Deregulation, ownership and efficiency change in Indian banking: an application of stochastic frontier analysis, in: Ghosh, R., Neogi, C. (Eds.), Theory and Application of Productivity and Efficiency, Econometric and DEA Approach. India, Macmillan, pp. 125-156. 
Leightner, J. E., Lovell. C. A. K., 1998. The impact of financial liberalization on the performance of Thai banks. Journal of Economics and Business 50, 115-131.

Matthews, K., Murinde V., Zhao, T., 2007. Competitive conditions among the major British banks. Journal of Banking and Finance 31, 2025-2042.

Maudos, J., Fernandez De Guevara, J., 2004. Factors explaining the interest margin in the banking sectors of the European Union. Journal of Banking and Finance 28, 2259-2281.

Megginson. W., 2005. The economics of bank privatization. Journal of Banking and Finance 29, 1931-1980.

Mueller, D., 1977. The persistence of profits above the norm. Economica 44, 369-380.

Mueller, D., 1986. Profit in the Long Run. Cambridge: Cambridge University Press.

Nickell S., Nicolitsas D., Dryden, N., 1997. What Makes Firms Perform Well. European Economic Review, 783 - 796.

Narasimhan Committee Report. (1991 and 1998). Report of the Committee on the Financial Sector Reforms (New Delhi: Ministry of Finance).

Paul, C. M. J., 1999. Cost Structure and the Measurement of Economic Performance. Kluwer Academic Publishers.

Pinho, P.S., 2000. The impact of deregulation on price and non-price competition in the Portuguese deposits market. Journal of Banking and Finance 24, 1515-1533.

Prasad, A., Ghosh, S., 2005. Competition in Indian Banking. IMF Working Papers 05/141, International Monetary Fund.

Salvanes, K. G., Tjotta, S., 1998. A note on the importance of testing for regularity for estimated flexible functional forms. Journal of Productivity Analysis 9, 133-143. 
Sealey, C, Lindley, J.T., 1977. Inputs, Outputs and a theory of production and cost at depositary financial institutions. Journal of Finance 32, 1251-1266.

Sensarma, R., 2005. Cost and profit efficiency of Indian banks during 1986-2003. Economic and Political Weekly 40, 1190-1197.

Stevenson, R., 1980. Measuring technological bias. American Economic Review 70,162-73

Vickers, J., 1995. Concepts of competition. Oxford Economic Papers 47, 1-23.

Zhao, T., Casu, B., Ferrari, A., 2008. Deregulation and productivity growth: a study of Indian commercial banking. International Journal of Business Performance Management, $10,4,318-343$. 
Table 1: Summary of the Indian banking industry (1992 - 2004)

\begin{tabular}{|c|c|c|c|c|c|c|c|c|c|c|}
\hline & \multicolumn{2}{|c|}{ Public } & \multicolumn{2}{|c|}{$\begin{array}{c}\text { Domestic } \\
\text { private }\end{array}$} & \multicolumn{2}{|c|}{ Foreign } & \multicolumn{4}{|c|}{ Total Banking Sector } \\
\hline & $\begin{array}{l}\text { N. of } \\
\text { banks }\end{array}$ & $\begin{array}{c}\text { Mkt } \\
\text { Share }\end{array}$ & $\begin{array}{l}\text { N. of } \\
\text { banks }\end{array}$ & $\begin{array}{c}\text { Mkt } \\
\text { Share }\end{array}$ & $\begin{array}{l}\text { N. of } \\
\text { banks }\end{array}$ & $\begin{array}{l}\text { Mkt } \\
\text { Share }\end{array}$ & $\begin{array}{l}\text { N.of } \\
\text { banks }\end{array}$ & HHI & CR5 & $\sigma^{2}$ \\
\hline 1992 & 28 & 0.885 & 25 & 0.042 & 24 & 0.072 & 77 & 0.102 & 0.516 & 0.00116 \\
\hline 1995 & 27 & 0.861 & 32 & 0.064 & 27 & 0.073 & 86 & 0.079 & 0.463 & 0.00078 \\
\hline 1998 & 27 & 0.743 & 34 & 0.140 & 42 & 0.116 & 103 & 0.072 & 0.446 & 0.00060 \\
\hline 2000 & 27 & 0.712 & 32 & 0.177 & 42 & 0.110 & 101 & 0.072 & 0.445 & 0.00061 \\
\hline 2004 & 27 & 0.745 & 30 & 0.185 & 33 & 0.069 & 90 & 0.064 & 0.415 & 0.00059 \\
\hline
\end{tabular}

Note: Market Share, Herfindahl-Hirschman Index (HHI) and Five-firm Concentration Ratio (CR5) are calculated relative to total assets. $\sigma^{2}$ measures the market shares' variance about the mean, i.e $1 / \mathrm{n}$.

Data source: Reserve Bank of India, author's calculation 
Table 2: Descriptive Statistics of selected banking indicators

\begin{tabular}{|c|c|c|c|c|c|}
\hline & 1992 & 1995 & 1998 & 2002 & 2004 \\
\hline (1) Implicit deposit rate ${ }^{a}$ & 0.065 & 0.056 & 0.076 & 0.074 & 0.048 \\
\hline (2) Implicit credit rate ${ }^{b}$ & 0.155 & 0.11 & 0.136 & 0.108 & 0.095 \\
\hline (3) Loanable fund price ${ }^{c}$ & 0.080 & 0.063 & 0.081 & 0.075 & 0.052 \\
\hline Spread A = (2)-(1) & 0.093 & 0.053 & 0.06 & 0.034 & 0.047 \\
\hline Spread B = (2)-(3) & 0.075 & 0.047 & 0.055 & 0.033 & 0.043 \\
\hline Total loans/total earning assets ${ }^{\mathrm{d}}$ & 0.603 & 0.588 & 0.578 & 0.541 & 0.510 \\
\hline Government security/total investment ${ }^{\mathrm{e}}$ & 0.629 & 0.664 & 0.664 & 0.726 & 0.793 \\
\hline $\mathrm{SRL}^{\mathrm{f}}$ & 0.339 & 0.349 & 0.323 & 0.373 & 0.416 \\
\hline Fee-based income/ total income ${ }^{g}$ & 0.134 & 0.138 & 0.154 & 0.196 & 0.237 \\
\hline
\end{tabular}

Notes: ${ }^{a}$ implicit deposit rate $=$ interest paid on deposits/ total deposits

${ }^{\mathrm{b}}$ implicit credit rate $=$ interest income received on loans/total loans.

${ }^{\mathrm{c}}$ loanable fund price $=$ total interest rate payment/total deposits and money market borrowing.

${ }^{\mathrm{d}}$ total earning assets $=$ total loans and total investment.

${ }^{\mathrm{e}}$ total investment = government securities, other approved securities, shares, debentures and bonds, subsidiaries and joint ventures and other investment outside India.

${ }^{\mathrm{f}} \mathrm{SRL}=$ Statutory Liquidity Ratio.

${ }^{\mathrm{g}}$ total income $=$ fee-based income and total interest income. 
Table 3: Data descriptive statistics

\begin{tabular}{|c|c|c|c|c|c|c|}
\hline \multicolumn{2}{|l|}{ Variable } & Mean & Median & Min & Max & Stdev \\
\hline \multirow{4}{*}{$\begin{array}{l}\text { Observed total } \\
\text { operating cost } \\
\text { (VC) }\end{array}$} & $\begin{array}{l}\text { Industry } \\
\text { average }\end{array}$ & 6792.97 & 2645.63 & 12.06 & 137723.5 & 13991.57 \\
\hline & $\begin{array}{l}\text { Public } \\
\text { banks }\end{array}$ & 13334.11 & 8361.23 & 1595.03 & 137723.5 & 19068.15 \\
\hline & $\begin{array}{l}\text { Domestic } \\
\text { private }\end{array}$ & 2515.55 & 961.77 & 12.06 & 48812.32 & 6392.24 \\
\hline & $\begin{array}{l}\text { Foreign } \\
\text { banks }\end{array}$ & 1733.94 & 502.99 & 66.22 & 14875.62 & 2636.76 \\
\hline \multirow[t]{4}{*}{$\begin{array}{l}\text { Performing } \\
\text { loans (Q1) }\end{array}$} & $\begin{array}{l}\text { Industry } \\
\text { average }\end{array}$ & 31965.98 & 12614.72 & 9.50 & 667624 & 65969.72 \\
\hline & $\begin{array}{l}\text { Public } \\
\text { banks }\end{array}$ & 60830.81 & 33008.23 & 7235.36 & 667624 & 87848.62 \\
\hline & $\begin{array}{l}\text { Domestic } \\
\text { private }\end{array}$ & 14444.2 & 4616.51 & 81.05 & 285287.2 & 40729.11 \\
\hline & $\begin{array}{l}\text { Foreign } \\
\text { banks }\end{array}$ & 8137.37 & 2405.18 & 9.50 & 67436.93 & 12640.38 \\
\hline \multirow[t]{4}{*}{$\begin{array}{l}\text { Other earning } \\
\text { assets (Q2) }\end{array}$} & $\begin{array}{l}\text { Industry } \\
\text { average }\end{array}$ & 31112.19 & 10447.18 & 24.66 & 1028343 & 77491.06 \\
\hline & $\begin{array}{l}\text { Public } \\
\text { banks }\end{array}$ & 62893.92 & 37634.76 & 4804.94 & 1028343 & 110142.9 \\
\hline & $\begin{array}{l}\text { Domestic } \\
\text { private }\end{array}$ & 10216.4 & 3758.28 & 24.66 & 237657.5 & 26783.96 \\
\hline & $\begin{array}{l}\text { Foreign } \\
\text { banks }\end{array}$ & 6657.15 & 1681.06 & 90.62 & 73062.98 & 11018.36 \\
\hline \multirow[t]{4}{*}{$\begin{array}{l}\text { Fee-based } \\
\text { income (Q3) }\end{array}$} & $\begin{array}{l}\text { Industry } \\
\text { average }\end{array}$ & 1236.71 & 468.68 & 0.01 & 33331.54 & 2734.48 \\
\hline & $\begin{array}{l}\text { Public } \\
\text { banks }\end{array}$ & 2198.94 & 1163.38 & 225.95 & 33331.54 & 3663.34 \\
\hline & $\begin{array}{l}\text { Domestic } \\
\text { private }\end{array}$ & 589.53 & 167.90 & 0.48 & 15042.3 & 1853.33 \\
\hline & $\begin{array}{l}\text { Foreign } \\
\text { banks }\end{array}$ & 512.43 & 118.61 & 0.01 & 3963.65 & 848.22 \\
\hline \multirow[t]{4}{*}{$\begin{array}{l}\text { Loanable fund } \\
\text { price (W1) }\end{array}$} & $\begin{array}{l}\text { Industry } \\
\text { average }\end{array}$ & 0.079 & 0.074 & 0.017 & 1.07 & 0.41 \\
\hline & $\begin{array}{l}\text { Public } \\
\text { banks }\end{array}$ & 0.072 & 0.073 & 0.038 & 0.103 & 0.010 \\
\hline & $\begin{array}{l}\text { Domestic } \\
\text { private }\end{array}$ & 0.074 & 0.074 & 0.017 & 0.121 & 0.014 \\
\hline & $\begin{array}{l}\text { Foreign } \\
\text { banks }\end{array}$ & 0.09 & 0.08 & 0.036 & 1.07 & 0.074 \\
\hline \multirow{4}{*}{$\begin{array}{l}\text { Non-operating } \\
\text { cost r price } \\
\text { (W2) }\end{array}$} & $\begin{array}{l}\text { Industry } \\
\text { average }\end{array}$ & 0.026 & 0.026 & 0.0044 & 0.33 & 0.014 \\
\hline & $\begin{array}{l}\text { Public } \\
\text { banks }\end{array}$ & 0.028 & 0.027 & 0.017 & 0.044 & 0.0047 \\
\hline & $\begin{array}{l}\text { Domestic } \\
\text { private }\end{array}$ & 0.025 & 0.025 & 0.006 & 0.047 & 0.006 \\
\hline & $\begin{array}{l}\text { Foreign } \\
\text { banks }\end{array}$ & 0.024 & 0.021 & 0.0044 & 0.33 & 0.024 \\
\hline
\end{tabular}


Table 4: ML estimates of the translog cost frontier [equations (3) and (4)]

\begin{tabular}{|c|c|c|c|}
\hline Variable & Parameter & Estimate & Standard error \\
\hline \multicolumn{4}{|l|}{ Cost Function } \\
\hline Intercept & $\beta_{0}$ & 11.256 & $0.022 * *$ \\
\hline $\ln y_{1}$ & $\alpha_{1}$ & 0.539 & $0.027 * *$ \\
\hline $\operatorname{lny}_{2}$ & $\alpha_{2}$ & 0.442 & $0.026 * *$ \\
\hline $\ln _{3}$ & $\alpha_{3}$ & 0.002 & 0.013 \\
\hline $\ln _{1}$ & $\beta_{1}$ & 0.886 & $0.035^{* *}$ \\
\hline $\ln y_{1} * \ln y_{1}$ & $\alpha_{11}$ & 0.070 & $0.012 * *$ \\
\hline $\ln y_{1} * \ln y_{2}$ & $\alpha_{12}$ & -0.078 & $0.017 * *$ \\
\hline $\ln y_{1} * \ln y_{3}$ & $\alpha_{13}$ & 0.022 & $0.005 * *$ \\
\hline $\ln y_{2} * \ln y_{2}$ & $\alpha_{22}$ & 0.108 & $0.020 * *$ \\
\hline $\ln y_{2} * \ln y_{3}$ & $\alpha_{23}$ & -0.025 & $0.004 * *$ \\
\hline $\ln y_{3} * \ln y_{3}$ & $\alpha_{33}$ & -0.002 & 0.002 \\
\hline $\ln \mathrm{w}_{1} * \ln \mathrm{w}_{1}$ & $\beta_{11}$ & -0.047 & $0.025^{*}$ \\
\hline $\ln w_{1} * \ln y_{1}$ & $\delta_{11}$ & -0.074 & $0.017 * *$ \\
\hline $\ln w_{1} * \ln y_{2}$ & $\delta_{12}$ & 0.074 & $0.017 * *$ \\
\hline $\ln w_{1} * \ln y_{3}$ & $\delta_{13}$ & -0.016 & 0.012 \\
\hline $\mathrm{T}$ & $\theta$ & 0.074 & $0.008 * *$ \\
\hline $\mathrm{T}^{*} \mathrm{~T}$ & $\lambda$ & -0.009 & $0.001 * *$ \\
\hline $\ln y_{1} * \mathrm{~T}$ & $\theta_{1}$ & -0.012 & $0.003 * *$ \\
\hline $\ln y_{2} * \mathrm{~T}$ & $\theta_{2}$ & 0.016 & $0.003 * *$ \\
\hline $\ln y_{3} * \mathrm{~T}$ & $\theta_{3}$ & -0.003 & $0.001 * *$ \\
\hline $\ln _{1} * \mathrm{~T}$ & $\zeta_{1}$ & -0.035 & $0.004 * *$ \\
\hline $\mathrm{R}$ & $\alpha_{\mathrm{r}}$ & 0.069 & $0.027 * *$ \\
\hline \multicolumn{4}{|l|}{ Inefficiency model } \\
\hline Intercept & $\delta_{0}$ & -0.937 & $0.299 * *$ \\
\hline Df & $\overline{\delta_{1}}$ & -0.779 & $0.410 * *$ \\
\hline $\mathrm{Dp}$ & $\delta_{2}$ & 1.172 & $0.296 * *$ \\
\hline TDf & $\delta_{3}$ & 0.256 & $0.094 * *$ \\
\hline TDp & $\delta_{4}$ & -0.313 & $0.110 * *$ \\
\hline $\mathrm{T}$ & $\delta_{5}$ & 0.095 & 0.086 \\
\hline $\mathrm{R}$ & $\delta_{6}$ & -1.406 & $0.486 * *$ \\
\hline RT & $\delta_{7}$ & 0.213 & $0.095 * *$ \\
\hline RDf & $\delta_{8}$ & 1.658 & $0.470 * *$ \\
\hline $\mathrm{RDp}$ & $\delta_{9}$ & -0.398 & 0.312 \\
\hline RTDf & $\delta_{10}$ & -0.311 & $0.095 * *$ \\
\hline RTDp & $\delta_{11}$ & 0.265 & $0.107 * *$ \\
\hline $\mathrm{T} * \mathrm{~T}$ & $\delta_{12}$ & -0.008 & $0.004 * *$ \\
\hline$\sigma^{2}$ & & 0.037 & 0.003 \\
\hline$\gamma$ & & 0.785 & $0.036 * *$ \\
\hline Log likelihood function & & 578.22 & \\
\hline
\end{tabular}

Note: $\sigma^{2}={\sigma_{u}}^{2}+{\sigma_{v}}^{2}, \gamma=\sigma_{u}{ }^{2} / \sigma^{2}$.*, **, significant at $10 \%$ and $5 \%$ respectively. 
Table 5: Competition Dynamics in the Lending Market [equation (6)]

\begin{tabular}{|l|l|}
\hline$\alpha$ & $.8709^{* * *}$ \\
& $(.0455)$ \\
\hline$\gamma_{\mathrm{p}}$ & $-.0921^{*}$ \\
& $(.0510)$ \\
\hline$\lambda_{1993}$ & -0.007 \\
& $(.0313)$ \\
\hline$\lambda_{1994}$ & $.0441^{* *}$ \\
& $(.0217)$ \\
\hline$\lambda_{1995}$ & -.0130 \\
\hline$\lambda_{1996}$ & $(.0214)$ \\
\hline$\lambda_{1997}$ & $.1059^{* * *}$ \\
\hline$\lambda_{1998}$ & $(.0149)$ \\
\hline$\lambda_{1999}$ & $.1175^{* * *}$ \\
\hline$\lambda_{2000}$ & $(.0179)$ \\
\hline$\lambda_{2001}$ & $-.0606^{* * *}$ \\
& $(.0223)$ \\
\hline$\lambda_{2002}$ & .0108 \\
& $(.0144)$ \\
\hline$\lambda_{2003}$ & $.0263^{*}$ \\
\hline$\lambda_{2004}$ & $(.0138)$ \\
\hline Adjusted R-squared & $.0665^{* * *}$ \\
\hline Root MSE & $(.0202)$ \\
\hline Pro>F(14, 64) & $.0724 * * *$ \\
\hline & $(.0164)$ \\
\hline & $.1089^{* * *}$ \\
& $(.0229)$ \\
\hline & $.0751^{* * *}$ \\
& $(.0277)$ \\
\hline & 0.84 \\
\hline & 0.15 \\
\hline & 0.00 \\
\hline
\end{tabular}

Note: the figures in bracket are standard errors that are asymptotically robust to both heteroskedasticity and serial correlation. $*, * *, * *$, indicate significance at $10 \%, 5 \%$ and $1 \%$ levels respectively. 
Figure 1: Average efficiency levels per ownership category

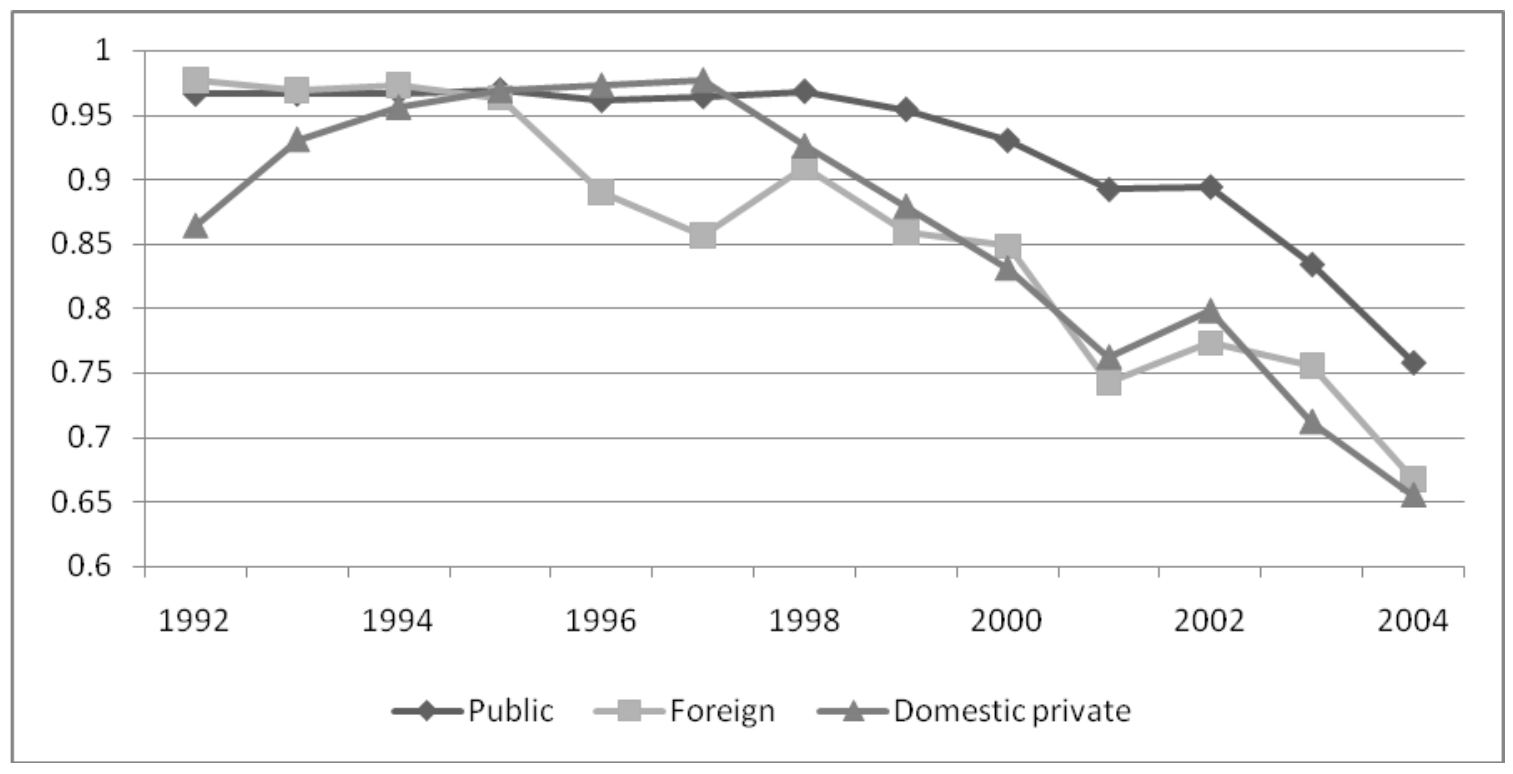

